\title{
EFFECT OF PHYSIOTHERAPY ON VITAL CAPACITY BEFORE MAJOR ABDOMINAL SURGERY IN CANCER PATIENTS: A SYSTEMATIC REVIEW
}

\author{
NIKOLINA ŠANTEK ${ }^{1}$ and IVA KIRAC ${ }^{2}$ \\ ${ }^{1}$ Department of Rheumatology, Physical and Rehabilitation Medicine, Clinic Unit of Rehabilitation \\ of Cancer Patients, Sestre milosrdnice University Hospital Center, Zagreb, Croatia; \\ ${ }^{2}$ Department of Surgical Oncology, University Hospital for Tumors, Sestre milosrdnice University \\ Hospital Center, Zagreb, Croatia
}

\begin{abstract}
Summary
Introduction: Cancer is one of the leading causes of death worldwide. However, if diagnosed in an operable stage, it is treated as a chronic disease. As such, long-term results and quality of life requirements imposed a comprehensive approach. Prehabilitation programs encompassing nutritional, physical, and psychological components improved the recovery and minimized the complication rate after surgery. We will focus on physiotherapy as part of prehabilitation in this review.

Methods: For systematic search, we used the MEDLINE/PubMed (National Library of medicine), Cochrane Central Register of Controlled Trials (Wiley), Embase (Elsevier, Web of Science, and Cochrane database of systematic reviews. The last search update was on 15th December 2020. The search included randomized clinical trials or quasi-randomized clinical trials evaluating exercise or other non-pharmacological preoperative interventions in gastrointestinal cancers.

Results: The ten trials included 1058 patients, 535 (50,6\%) patients were in the experimental group, and 523 (49,4\%) patients were in the control group. Bicycle exercise training was the best-ranked intervention with the standard mean difference (SMD) of 1,4077 (95\% C.I. is $0,7018-2,1135)$ to improve vital functional capacity (s, VO^ 2 at $\left.\mathrm{u}^{\wedge} \mathrm{L}\right)$. Short-term exercise affected inspiratory muscle strength, and SMD was 1,1819 (95\% C.I.,2953 - 2,0684). Short- term intensity training program SMD was 0,8356 (95\% C.I. 0,2042 - 1,4669), and short- term intensity program for muscle endurance 0,8156 (95\% C.I. 0,2042 -1,4669). improves respiratory muscle endurance. Small effect was shown on quality of life in high-intensity cycling interval training SMD 0,7439(95\%C.. 0,0856 - 1,4023), WHO performance status in bicycle exercise training SMD 0,7068( 95\% C.I. 0,0547 - 1,3589), mean number of complication in high-intensity endurance training SMD 0,3606 (95\% C.I. 0,0072 - 0,7141).

Conclusion: Although exercise therapy has been shown to improve vital capacity and respiratory muscle strength, there was a lack of comparison between different exercises. Evidence from these indirect-comparisons studies indicated that physical activity should be encouraged during the preoperative period before oncologic surgery.
\end{abstract}

KEYWORDS: exercise, rehabilitation, cancer, major abdominal surgery

\section{INTRODUCTION}

Cancer is a significant public health problem worldwide (1). Cancer is expected to rank as the

Corresponding author: Nikolina Šantek, Department of Rheumatology, Physical and Rehabilitation Medicine, Clinic Unit of Rehabilitation of Cancer Patients, Sestre milosrdnice University Hospital Center, Iica 197, 10000 Zagreb, Croatia; email: nikolina.santek@kbcsm.hr leading cause of death and the single most important barrier to increasing life expectancy in every country of the world in the 21st century. According to estimates from the World Health Organization (WHO) in 2015, cancer is the first or second leading cause of death under 70 years in 91 of 172 countries, and it ranks third or fourth in an additional 22 countries. Cancer incidence and mortality are rapidly growing worldwide (2). 
Surgery is the most common and still the most effective cancer treatment (3). About 300 million patients undergo surgery worldwide each year, with more procedures in high-income countries (4). Findings from epidemiological studies suggest that 4.8 billion people cannot access safe surgical treatments and that at least 143 million additional procedures are required each year, primarily in low and middle-income countries $(4,5)$. However, as health care systems develop to improve access to surgical treatments, the number of patients who suffer postoperative complications will also increase. Postoperative complications increase treatment costs and reduce both life expectancy and quality of life (5).

Advances in diagnostic procedures, surgical technology, and perioperative care have improved safety and patient outcomes following cancer's surgical resection. The mortality and morbidity rates of primary surgical resection are between $4 \%$ and $10 \%$ (6) and $20 \%$ and $60 \%$, respectively (7). Postoperative complications prolong hospital stay, readmissions, and costs, significantly impacting patient functioning and quality of life, and may have long-term implications on mortality. The impact of the stress of cancer and surgery is notable during the recovery period and is characterized by fatigue, decreased appetite, pain, reduced mobility and mental concentration. When the impact of abdominal surgery is evaluated using functional capacity measures, only $30 \%$ of older adults recovere to preoperative levels at eight weeks after surgery and $50 \%$ after six months (8). Poor preoperative physical performance has been shown to increase the number of postoperative complications and mortality risk (9).

Prehabilitation is an intervention that capitalizes on the waiting period before surgery with preoperative strategies designed to optimize the patient's physical condition to promote an earlier postoperative recovery (10). Also, rehabilitation improves patient health in anticipation of a physiological stressor such as major surgery (11).

Cancer prehabilitation has been defined by Sliver and Baima as a process on the cancer continuum of care that occurs between the time of cancer diagnosis and the beginning of acute treatment and includes physical and psychological assessments that establish a baseline functional level, identify impairments, and provide interventions that promote physical and men- tal health to reduce the incidence and severity of future impairments (12).

Preoperative physical status is often reduced in patients with cancer and is predictive of postoperative complications and poor prognosis. Therefore, preoperative status is an essential factor in improving postoperative outcomes in these patients (13). Over the last few years, several studies have evaluated the possibility of enhancing preoperative physical function by using prehabilitation to overcome surgical stress and improve postoperative recovery times (14).

Physical exercise is defined as an activity that is planned, structured, repetitive, and purposeful to improve or maintain one or more components of physical fitness, i.e., endurance, muscular strength, and body composition. Physical exercise has, in general, a positive impact on many biological processes such as energy expenditure, insulin resistance, inflammation, and most body organs and tissues. In cancer patients, there is evidence that physical exercise reduces fatigue, improves the quality of life, and relieves many of the adverse side effects experienced during and after treatment $(15,16)$.

\section{METHODS}

\section{Selection of studies}

We systematically searched MEDLINE/ PubMed (National Library of medicine), Cochrane Central Register of Controlled Trials (Wiley), Embase (Elsevier, Web of Science and Cochrane database of systematic reviews. The search strategy developed relevant keywords and controlled vocabulary that included: preoperative exercise, prehabilitation, oncologic surgery, gastrointestinal cancer, and randomized controlled trials. We last updated the search on 15th December 2020.

\section{Data extraction}

Individual reviewers screened titles and abstracts to identify potentially relevant articles. The senior author resolved discrepancies in judgment. In case of disagreement, we reached a consensus through discussion. At this stage, studies were excluded only if the available information in the title or the abstract made it clear that the article was not eligible. Full texts were retrieved for the other papers and read independently by these reviews. 


\section{Assessment of Risk of bias}

We used the Cochrane risk-of-bias (RoB)tool published in the Cochrane handbook for systematic reviews of interventions, random sequence generation items, allocation concealment, baseline differences between groups, and blinding of participants, blinding of therapists, and blinding of assessors, incomplete outcome data, and intention-to-treat analysis. We provided RoB only to give a detailed overview of the characteristics of the included studies (i.e., we did not use RoB to exclude studies)

\section{Inclusion and exclusion criteria}

\section{Inclusion criteria of study selection}

We included published randomized clinical trials or quasi-randomized clinical trials evaluating all kinds of exercise or other non-pharmacological interventions such as relaxation intervention in cancer patients before surgery for gastrointestinal cancer, liver cancer, colon, and rectal cancer.

\section{Exclusion criteria of study selection}

We excluded trials comparing drugs or nutritional supplementations, acupuncture, electroacupuncture, acupressure, moxibustion, or healing without touching the patients.

\section{Endpoints}

The primary endpoint for this study included the measurement of functional vital capacity. The studies included had functional vital capacity quantification with a 6-minute walk test and/or inspiratory muscle strength. We used the percentage of patients with any complication as defined by the authors of the original study. We did not include readmissions, which were evaluated separately.

The secondary endpoint was the quality of life and health survey. Safety was defined as a report of any serious or nonserious adverse events (A.E.s) of any grade (17).

\section{Data synthesis and analysis}

Because functional vital capacity was assessed with various tests, we used standard mean difference (SMD). The SMD measure of effect is used when studies report efficacy in terms of a continuous measurement, such as score on a painintensity rating scale. The SMD is also known Cohen's $d$. An SMD of zero means that the new treatment and the placebo have equivalent effect. If improved is associated with higher scores of the outcome measure, SMDs greater than zero indicate the degree to which treatment is less efficacious than placebo.

Cohen offered the following guidelines for interpreting the magnitude of the SMD, small, SMD = 0,2 , medium SMD $=0,5$, large, $\mathrm{SMD}=0,8(18)$.

We selected the SMD differences between the direct and indirect comparisons to evaluate the fundamental assumption of consistency: that direct and indirect evidence is compatible or that all studies are exchangeable. Heterogeneity was assessed using Higgins I2 for each pairwise comparison (19).

\section{RESULTS}

The database's systematic search yielded 84 articles, we screened 29 full texts, and finally included ten articles for further qualitative and quantitative analysis (20 - 29) - the dates of publication range from 2010 to 2019. Of the included articles, all included articles reported on the patients before major abdominal surgery exercise treatment. The duration of intervention ranged from 2 to 6 weeks. The ten trials included 1058 patients, $535(50,6 \%)$ patients were in the experimental group, and $523(49,4 \%)$ patients were in the control group.

The mean S.D. patient age in the experimental group was 67,8 years and in the control group was 67,8 years. In included studies, $35,92 \%$ of patients were women.

Most of the studies reported patients undergoing major abdominal surgery, various diagnosis $(\mathrm{N}=730,69 \%)$, followed by studies reported colorectal surgery $(\mathrm{N}=248,23,4 \%)$, rectal surgery $(n=39,3,7 \%)$ and liver surgery $(n=57,5,39 \%)$.

\section{RoB 2 of included trials}

The random sequence generation was adequate in all trials; allocation concealment was not problematic in all trials. One study did not balance the baseline characteristics $(10 \%)$. Patients were not blinded in two trials (20\%). Therapists were blinded in one trial (10\%). More than $4,5 \%$ of 
Lib Oncol. 2021;49(1):39-47

Table 1.

Standard mean difference of primary outcome measurement

\begin{tabular}{|l|c|c|c|}
\hline Interventions & SMD & $95 \%$ C.I. & P value \\
\hline Bicycle exercise training & 1,4077 & $0,7018-2,1135$ & 0,129682 \\
\hline Short term exercise Inspiratory muscle strength & 1,1819 & $0,2953-2,0684$ & 0,204608 \\
\hline Short term intensity exercise program & 0,8356 & $0,2042-1,4669$ & 0,103766 \\
\hline Short-term intensity exercise program (muscle endurence) & 0,8156 & $0,2042-1,4669$ & 0,103766 \\
\hline High-intensity cycle interval training & 0,7716 & $0,1116-1,4316$ & 0,113389 \\
\hline Pre-operative inspiratory muscle training & 0,7134 & $0,1725-1,2545$ & 0,076145 \\
\hline Aerobic and resistance exercise & 0,6275 & $0,2545-1,0002$ & 0,036189 \\
\hline High intensity endurance training & 0,6031 & $0,2446-0,9616$ & 0,033457 \\
\hline Bike/strength / walk/breathing & 0,3683 & $-0,0054-0,7421$ & 0,036366 \\
\hline Breathing exercise training session & 0,3152 & $0,1275-0,5028$ & 0,009163 \\
\hline
\end{tabular}

Table 2.

Standard mean difference of secondary outcome meassurment

\begin{tabular}{|c|c|c|c|}
\hline Interventions & SMD & 95\% C.I. & $P$ value \\
\hline Quality of life (high-intensity cycling interval training) & 0,7439 & $0,0856-1,4023$ & 0,112838 \\
\hline WHO performance status (bicycle exercise training) & 0,7068 & $0,0547-1,3589$ & 0,110683 \\
\hline Mean number of complication per patient (high-intensity endurance training) & 0,3606 & $0,0072-0,7141$ & 0,032522 \\
\hline Assessment of quality of life (inspiratory muscle strenght training) & 0,3195 & $-0,5061-1,1425$ & 0,176457 \\
\hline Quality of life - functional status (short-term intensity exercise program) & 0,3177 & $-0,2917-0,927$ & 0,096656 \\
\hline Quality of life (short-term intensity exercise program) & 0,0117 & $-0,5939-0,6172$ & 0,095456 \\
\hline Anxiety (bike/strenght vs. Walking/breathing) & 0,0109 & $-0,3597-0,3846$ & 0,03576 \\
\hline Legth of hospital stay (breathing exercise training) & 0,0089 & $-0,0975-0,2756$ & 0,009059 \\
\hline
\end{tabular}

drop-outs were present in $50 \%$ of the trials, and only $20 \%$ of the trials reported an intention-totreat analysis.

\section{Indirect-comparisons studies for primary outcome measurement}

The network consisted of 10 studies. Studies were reporting on two various interventions: three studies reported on the effect of respiratory muscle strength and breathing exercise, and seven studies reported on the various exercise training program (bicycle exercise, aerobic and resistance exercise, high-intensity endurance training, two short-term intensity exercise program for muscle endurance, high-intensity cycle interval training and bike/strength training versus walking/breathing program).

The effect size for the difference between all interventions is presented in table 1(20 - 29). Bicycle exercise training was the best-ranked intervention with the SMD of 1,4077 (95\% C.I. is 0,7018 $2,1135)$ to improve functional vital capacity (s,

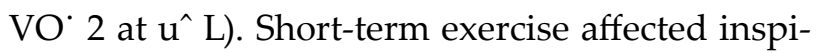
ratory muscle strength, and SMD was 1,1819 (95\% C.I.,2953-2,0684).

Short- term intensity training program SMD was 0,8356 (95\% C.I. 0,2042 - 1,4669), and shortterm intensity program for muscle endurence 0,8156 (95\% C.I. 0,2042 - 1,4669). improves improve respiratory muscle endurence. High-intensity cycling interval training improve oxygen uptake SMD is 0,7716 (95\% C.I. 0,1116-1,4316). --Inspiratory muscle strength training was been more effective than deep breathing SMD 0,7134 (95\% C.I. $0,1725-1,2545)$.

\section{Indirect-comparisons studies for secondary outcome measurement}

The network consisted of studies that describe the quality of life status. The majority of trials included quality of life questionnaires. The most applied questionnaire was (EORTC QLQC30). The effect size for the difference between all interventions is depicted in table 2. 
The result stresses that exercise training intervention has a small impact on the quality of life status, anxiety, and hospital stay. Small effect was shown on quality of life in high-intensity cycling interval training SMD 0,7439 (95\% C.I. 0,0856 1,4023), WHO performance status in bicycle exercise training SMD 0,7068 (95\% C.I. 0,0547 - 1,3589), mean number of complication in high-intensity endurance training SMD 0,3606 (95\% C.I. 0,0072$0,7141)$.

There were no significant changes in the quality of life assessment between the experimental and control groups in other studies.

\section{DISCUSSION}

\section{Summary of main results}

This indirect-comparison of the randomized clinical trial includes studies evaluating the effect of physical exercise intervention before major abdominal oncologic surgery on vital capacity and quality of life.

We found evidence that bicycle interval training has moderate-to-high effect size during preoperative cancer treatment substantially more than usual care (95\% C.I. is higher than 0,7), Similar results have Inspiratory muscle strength, aerobic and resistance exercise, high intensity endurance training short term intensity exercise program where is $95 \%$ C.I. higher of 0,2 . Pre-operative inspiratory muscle training, breathing exercise training session for prevent PPC, High intensity cycle interval training and bike/strength vs walk/ breathing have a small effect size, $95 \%$ C.I. is lower than 0,2 .

Also, we found that Quality of life (high-intensity cycling interval training), WHO performance status (bicycle exercise training), mean number of complication per patient (high-intensity endurance training) have a small effect size of $95 \%$ C.I., lower than 0,2 . Other results of quality of life $95 \%$ C.I. were less than zero.

The ranking of the different types of preoperative exercise's effectiveness may help healthcare professionals (e.g., oncologists, surgeons, physiotherapists, nurses of family medicine specialists) and patients with cancer in their shared clinical decision-making process. For example, the patient's preferences, contraindications, availability, and the interventions' costs may influence their decision. Our ranked interventions help patients and practitioners prioritize evidence-based interventions during and after treatment.

\section{Quality of the evidence}

The strength of indirect-comparison of randomized clinical trials was to include a set of various exercise interventions (without nutrition support or other prehabilitation procedure) for cancer patients before major abdominal surgery. This study's major limitation was a small number of studies and a small number of included participation. Another limitation of this study was difficulty in classifying the intervention described in the included studies. We have a different kind of intervention combination. Second, because specific information on training intensity or the extent of exercises lacked in most of the studies, it was not possible to analyze the effect of high versus low training intensity or high versus low exercise volume.

\section{Comparison with other studies}

It is well-known that exercise therapy has an impact on improving cardiorespiratory fitness and vital capacity. Also, physical exercise reduces tumor growth, and it has a significant benefit of the patient s quality of life (30-46). This review used different exercises like aerobic exercise, anaerobic exercise, resistance exercise, high-intensity interval training, and moderate-intensity interval training.

There have been several systematic reviews and meta-analyses evaluating the effect of exercise therapy in oncologic patients during cancer of preoperative treatment, and most of them do favor exercise intervention compared with usual care $(10,12-16,47-54)$. This study's conclusion is based on similar sets of published studies as used in another meta-analysis of systematic reviews. Also, the findings suggest that physical exercise before cancer surgery improves physical fitness and quality of life, reduces postoperative pulmonary complications, reduces hospital stay, decreases incidences of postoperative complications, and affects muscle strength and mass.

Different working mechanisms may explain the effectiveness of the interventions included in this study. Active exercises (e.g., resistance training, aerobic training, high-intensity interval train- 
ing, etc.) with or without nutrition support may counteract the decreased level of activity before cancer surgery and improve physical capacity. Furthermore, higher physical activity levels may have a beneficial effect on physiological and psychological benefits, mental health performed in quality of life questionary.

Preoperative level of physical activity was associated with a faster self-assessment physical recovery after colorectal cancer surgery. Physical activity did not shown any associations with the primary outcome measure length of hospital stay. Assessment of physical activity level preoperatively could be used for prognostic reasons (55). Prospective study on patients after radical resection of colorectal cancer found that the ERAS protocol attenuates the surgical stress response and accelerates postoperative recovery (56).

\section{Implication for practice}

These findings may have important clinical implications. They suggest that the effectiveness of various exercise interventions varies depending on the patient's cancer treatment status. During the preoperative cancer treatment cycle, a shortterm high-intensity exercise program's exercise program seems to have the most significant effect. The health professionals consider physical activity, aerobic exercise, endurance training, resistance training of inspiratory muscle training as beneficial interventions. Unfortunately, this study's results do not allow for a more detailed specification of the exercise modalities such as training intensity or exercise volume. Health professionals might consult the ranking of the interventions presented in this study when planning an optimal, individually adapted exercise program to reduce postoperative complications. Because some of the interventions included in this analysis showed quite a similar effect, health professionals now have a choice between various interventions and can, for example, take into account the individual patient's preferences.

\section{Implication for research}

This review indicates what type of exercise might be better suited to improve patients' vital capacity, but it does not suggest clear-cut exercise modalities. The current knowledge of exercise modalities such as training intensity, exercise vol- ume, resting intervals, and training frequency is not optimal.

\section{CONCLUSION}

Although, exercise therapy has been shown to be effective in improving vital capacity and respiratory muscle strength, there was a lack of concordance between different types of exercise. Evidence from these indirect-comparisons studies indicated that during the preoperative period before oncologic surgery, physical activity (such as aerobic training, anaerobic training, resistance training, high-intensity training, respiratory muscle training, or breathing exercise) showed similar moderate-to-large effect size.

\section{REFERENCES}

1. Sieger RL, Miller KD, et al. Cancer statistic 2019, CA Cancer J Clin 2019;69(1):7-34.

2. Bray F, Ferlay J, et al. Global Cancer Statistics 2018: GLOBOCAN Estimates of Inc.idence and Mortality Worldwide for 36 Cancers in 185 Countries. Ca Cancer J Clin. 2018;70:3-31.

3. Wieser TG, et al. Estimate of the global volume of surgery in 2012: an assessment supporting improved health outcomes. Lancet. 2015;385(Suppl 2):S11.

4. Weiser TG, Regenbogen SE, et al. An estimation of the global volume of surgery: a modelling strategy based on available data. Lancet. 2008;372:139-44.

5. Global patient outcomes after elective surgery: prospective cohort study in 27 low-, middle- and highincome countries The International Surgical Outcomes Study group. British Journal of Anaesthesia 2016;117 (5):601-9.

6. Rock CL, Doyle C, et al. Nutrition and physical activity guidelines for cancer survivors. CA Cancer J Clin. 2012;62(4):242e74.

7. Schmitz KH, Courneya KS, et al. American college of sports medicine roundtable on exercise guidelines for cancer survivors. Med Sci Sports Exerc. 2010;42(7): 1409-26.

8. Speck RM, Courneya KS, et al. An update of controlled physical activity trials in cancer survivors: a systematic review and meta-analysis. J Cancer Surviv. 2010; $4(2): 87-100$.

9. Spence RR, Heesch KC, et al. Exercise and cancer rehabilitation: a systematic review. Cancer Treat Rev. 2010; 36(2):185-94.

10. Gillis C, Buhler K, et al. Effects of nutritional rehabilitation, with and without exercise, on outcomes of patients who undergo colorectal surgery: a systematic review and meta-analysis. Gastroenterology. 2018;155 (2):391-410. 
11. Jain R. Gibson L, Goburn. Prehabilitation for surgical oncologic patient: Improving patient volition. Support Care Cancer 2018;26(11):3665-3667.

12. Fardi C, Gills C, et al. Promoting a culture of prehabilitation for the surgical cancer patient. Acta Oncol 2017;56(2):128-133.

13. Peraux E, Gilles C, et al. Effects of preoperative combined aerobic and resistance exercise training in cancer patients undergoing tumour resection surgery: A systematic review of randomised trials. Surg Oncol. 2018;27(3):584-594.

14. Valken K, van de Port IG, et al. The effects of preoperative exercise therapy on postoperative outcome: a systematic review. Clin Rehabil. 2011;25(2):99-111.

15. Speck RM, Courneya KS, et al. An update of controlled physical activity trials in cancer survivors: a systematic review and meta-analysis. J Cancer Surviv : Research and Practice. 2011;4(2):87-100.

16. Stene GB, Helbostad JL, et al. Effect of physical exercise on muscle mass and strength in cancer patient during treatment - a systematic review. Crit Rev Oncol Hematol. 2013;88(3):573-93.

17. Boutron I, Altman DG, et al. CONSORT statement for randomized trials of nonpharmacologic treatments: A 2017 update and a CONSORT extension for nonpharmacologic trial abstracts. Ann Intern Med. 2017;167: 40-47.

18. Faraone SV. Interpreting estimates of treatment effect, implications for managed care. P\&T. 2008;33(12):700703, and 710-711.

19. Dechartres A, Trinquart L, et al. Influence of trial sample size on treatment effect estimates: meta-epidemiological study. BMJ 2013;346:f2304.

20. West MA, Loughney L, et al. Effect of prehabilitation on objectively measured physical fitness after neoadjuvant treatment in preoperative rectal cancer: a blinded interventional pilot study. Br J Anaesth. 2014;144 (2):244-51.

21. Karlsson E, Farahnak P, et al. Feasibility of preoperative supervised home-based exercise in older adults undergoing colorectal cancer surgery - a randomized controlled design. PloS One 2019;14(7):e0219158.

22. Chen PB, Awasthi R, et al. Four-week prehabilitation program is sufficient to modify exercise behaviors and improve preoperative functional walking capacity in patients with colorectal cancer. Support Care Cancer. 2016;25(1):33-40.

23. Barberan-Garcia A, Lucy A, et al. Personalized prehabilitation in high-risk patients undergoing elective major abdominal surgery: a randomized blinded controlled trial. Ann Surg. 2018;267(1):50-56.

24. Dronkers JJ, Lamberts $\mathrm{H}$, et al. Preoperative exercise program for elderly patients scheduled for elective abdominal oncological surgery: a randomized controlled pilot study. Clin Rehabil. 2010;24(7):614-22.

25. Kulkarni SR, Fleteher E, et al. Preoperative inspiratory muscle training preserves postoperative inspiratory muscle strength following major abdominal surgery - a randomized pilot study. Ann R Coll Surg Engl. 2010;92(8):700-707

26. Boden I, Skinner HE, et al. Preoperative physiotherapy for the prevention of respiratory complication after upper abdominal surgery: pragmatic double-blinded multicentre randomised controlled trial. BMJ 2018; 360:j5916.

27. Dronkers JJ, Lamberts $\mathrm{H}$, et al. Preoperative therapeutic programme for elderly patients shedule for elective abdominal oncological surgery: a randomized controlled pilot study. Clin Rehabil. 2009;24(7):614-22.

28. Dunne DFJ, Jack $S$, et al. Randomized clinical trial of prehabilitation before planned liver resection. $\mathrm{Br} \mathrm{J}$ Surg. 2016;103(5):504-12.

29. Charli F, Charlebois $\mathrm{P}$, et al. Randomized clinical trial of prehabilitation in colorectal surgery. Br J Surg. 2010;97(8):1187-97.

30. Brown JC, Damjanov N, et al. A randomized dose-response trial of aerobic exercise and health-related, quality of life in colon cancer survivors. Psychooncology 2018;27(4):1221-1228.

31. De Lima C, Alves EL, et al. Anaerobic exercise reduces tumor growth, cancer cachexia and increases macrophage and lymphocyte response in Walker 256 tumorbearing rats. Eur J Appl Physiol. 2008;104:957-964.

32. West MA, Lythgoe D, et al. Cardiopulmonary exercise variables are associated with postoperative morbidity after major colonic surgery: a prospective blinded observational study. Br J Anaesth. 2014;112(4):665-71.

33. Dimeo CF, Thomas F, et al. Effect of aerobic exercise and relaxation training and fatigue and physical performance of cancer patients after surgery, a randomized controlled trial. Support Care Cancer 2004; 12:774-779.

34. Adams CS, DeLorey SD, et al. Effect of high-intensity interval training on fatigue and quality of life in testicular cancer survivors. Br J Cancer. 2018;118(10): 1313-1321.

35. Zielinski RM, Muenchow M, et al. Exercise delays allogeneic tumor growth and reduces intratumoral inflammation and vascularization. J Appl Physiol. 2004; 96:2249-2256.

36. Lee WJ, Neil D, et al. Exercise intolerance in cancer and the role of exercise therapy to reverse dysfunction. Lancet Oncol. 2009;10:598-605.

37. Lawrence AV, Hazuda PH, et al. Functional independence after major abdominal surgery in the elderly. J Am Coll Surg. 2004;199:762-772.

38. Li C, Carli F, et al. Impact of trimodal prehabilitation program a functional recovery after colorectal cancer surgery: a pilot study. Surg Endosc. 2013;27:1072-1082.

39. Shoyeb A, Weinstein $\mathrm{H}$, et al. Perioperative exercise echocardiography and perioperative cardiovascular outcome in elderly patient undergoing cancer surgery. Am J Geriatr Cardiol. 2006;15(6):338-44. 
40. Meyerhardt AJ, Giovannucci LE, et al. Physical activity and survival after colorectal cancer diagnosis. J Clin Oncol 2006;24(22):3527-34.

41. Wand B, Shelad GW, et al. Prehabilitation program improves outcomes of patient undergoing elective liver resection. J Surg Res. 2020;251:119-125.

42. Gillis C, Li O, et al. Prehabilitation versus rehabilitation, a randomized control trial in patient undergoing colorectal resection for cancer. Anaesthesiology 2014; 121:937-47.

43. Dronkers J, van Meeteren N, et al. Prevention of pulmonary complications after upper abdominal surgery by preoperative intensive inspiratory muscle training: a randomized controlled pilot study. Clin Rehabil. 2008;22(2):134-42.

44. Huang HG, Ismail $\mathrm{H}$, et al. Structured exercise program prior to major cancer surgery improves cardiopulmonary fitness: a retrospective cohort study. Support Care Cancer 2016;24:2277-2285.

45. Hardee PJ, Porter RR, et al. The effect of resistance exercise of all-cause mortality in cancer survivors. Mayo Clin Proc. 2014;98(8):1108-15.

46. Devin JL, Sax TA, et al. The influence of high-intensity compared with moderate-intensity exercise training on cardiorespiratory fitness and body composition in colorectal cancer survivors: a randomized controlled trial. J Cancer Surviv. 2015;10(3):467-79.

47. Hijazi Y, Condal U, et al. A systematic review of prehabilitation program in abdominal cancer surgery. Int J Surg. 2017;39:156-162.

48. Singht F, Newton UR, et al. A systematic review of pre-surgical exercise intervention studies with cancer patients. Surg Oncology 2013;22(2):92-104.
49. Santa Mina D, Clarke H, et al. Effect of total-body prehabilitation on postoperative outcomes: a systematic review and meta-analysis. Physiotherapy 2014;100(3): 196-207.

50. Mugele H, Freitag N, et al. High-intensity interval training in the therapy and aftercare of cancer patients: a systematic review with meta-analysis. J Cancer Surviv. 2019;13(2):205-223.

51. Gwendolyn T, Muhammad RT, et al. Prehabilitation before major intra-abdominal surgery: a systematic reviews of randomized controlled trials. Eur J Anaesth. 2019;36(12):933-945.

52. Moran J, Mockler D, et al. The ability of prehabilitation to influence of postoperative outcome after intraabdominal operation: a systematic review and metaanalysis. Surgery 2016;160(5):1189-1201

53. Vermillion AS, James A, et al. Preoperative exercise therapy for gastrointestinal cancer patients: a systematic review. Syst Rev. 2018;7(1):103.

54. Luther A, Gabriel J, et al. The impact of total-body prehabilitation on postoperative outcomes after major abdominal surgery: a systematic review. Word J Surg. 2018;42(9):2781-1791.

55. Onerup A, Bock D, et al. Is preoperative physical activity related to post-surgical recovery? - a cohort study of colorectal cancer patients. Int J Colorectal Dis. 2016;31(6):1131-40.

56. Ren L, Zhu D, et al. Enhanced recovery after surgery (ERAS) program attenuates stress and accelerates recovery in patients after radical resection for colorectal cancer: a prospective randomized controlled trial. World J Surg. 2012;36(2):407-14. 


\section{Sažetak \\ UTJECAJ FIZIOTERAPIJE NA VITALNI KAPACITET PRIJE VELIKIH ABDOMINALNIH OPERACIJA KOD BOLESNIKA S KARCINOMOM, SUSTABNI PREGLED LITERATURE}

\section{N. Šantek i I. Kirac}

Uvod: Karcinom je jedan od vodećih uzroka smrti u svijetu. Međutim, ako se dijagnosticira u operabilnoj fazi, liječi se poput kroničnih bolesti. Kao takvi, dugoročni rezultati i zahtjevi za kvalitetom života nametnuli su sveobuhvatan pristup. Programi prehabilitacije koji uključuju nutritivne, fizičke I psihološke komponente, poboljšali su oporavak I minimizirali stopu komplikacija nakon operacije. U ovom ćemo se preglednom radu usredotoćiti na fizioterapiju kao dio prehabilitacije.

Metode: Za sustavno pretraživanje koristili smo MEDLINE / PubMed (Nacionalna medicinska knjižnica), Cochraneov Centralni registar kontroliranih ispitivanja (Wiley), Embase (Elsevier, Web of Science i Cochrane baza podataka sustavnih pregleda). Posljednje ažuriranje pretraživanja bilo je 15. prosinca 2020. Pretraga je uključivala randomizirana klinička ispitivanja ili kvazi-randomizirana klinička ispitivanja koja ocjenjuju vježbanje ili druge nefarmakološke preoperativne intervencije kod karcinoma probavnog sustava.

Rezultati: Deset pokusa obuhvaćalo je 1058 bolesnika, 535 (50,6\%) bolesnika bilo je u eksperimentalnoj skupini, a 523 $(49,4 \%)$ bolesnika u kontrolnoj skupini. Trening s vježbama na biciklu bio je najbolje rangirana intervencija sa standardnom srednjom razlikom (SMD) od 1.4077 (95\% C.I. je 0,7018 - 2,1135) za poboljšanje vitalne funkcionalne sposobnosti (s, VO` 2 pri u^ L). Kratkotrajno vježbanje utjecalo je na snagu inspiratornih mišića, a SMD je iznosio 1,1819 (95\% C.I, 2953 - 2,6684). Program kratkotrajnog intenzivnog treninga SMD iznosio je 0,8356 (95\% C.I. 0,2042 - 1,4669), a program kratkotrajnog intenzivnog treninga za izdržljivost mišića 0,8156 (95\% C.I. 0,2042 - 1,4669). Pokazan je mali učinak na kvalitetu života u visokointenzivnom intervalnom treningu na biciklom SMD 0,7439 (95\% C.1. 0,0856 - 1,4023), status izvedbe prema WHO-u u treningu na biciklu SMD 0,7068 (95\% C.I. 0,0547 - 1,3589), srednji broj komplikacija u visokointenzivnom treningu izdržljivosti SMD 0,3606 (95\% C.I. 0,0072 - 0,7141).

Zaključak: Iako se pokazalo da fizioterapija vježbanjem poboljšava vitalni kapacitet i snagu respiratornih mišića, nije bilo usporedbe između različitih vrsta vježbanja. Dokazi iz ovih studija neizravne usporedbe ukazuju na to da tjelesnu aktivnost treba poticati tijekom preoperativnog razdoblja prije velikih abdominalnih kirurških zahvata kod onkoloških pacijenata.

KLJUČNE RIJEČI: vježbanje, prehabilitacija, karcinom, velike abdominalne operacije 